\title{
CHANGING DIMENSIONS OF RIGHT AGAINST SELF-INCRIMINATION: AN ANALYTICAL STUDY ${ }^{1}$
}

DOI:10.47743/rdc-2021-1-0003

Dr. Jasdeep KAUR ${ }^{2}$

\section{Abstract}

Right against self-incrimination is recognized as a Fundamental Right under the Indian Constitution. It is based on the maxim "nemo tenetur seipsum accusare" which implies that no man shall be obliged to be a witness against himself. The right is recognized in various International Conventions and Declarations. The right has also been incorporated as a right of accused in different countries. The Apex Court of India has emphasized time and again the significance of the right in its various Judgments. However, with the growth of Science and Technology, the dimensions of Right have undergone a considerable change. It has raised the issues of Testimonial Compulsion and violation of Rights of the accused. The present paper will be an attempt to examine the Impact of growing technology in relation to right against self-incrimination and effort will be made to analyze whether the growth of Science and Technology has in fact resulted or not in violation of the right.

Keywords: right against self-incrimination, human rights, Article 20 (3) of the Constitution of India

\section{Introduction}

Right against self-incrimination is recognized as a Fundamental Right under the Indian Constitution. It is also known as Right to Silence ${ }^{3}$. The right is based on the principle of "nemo debet prodere se ipsum", which covers the protection against selfincrimination ${ }^{4}$. The right to silence can be interpreted in three different ways. First is that as per the laws of India, the burden of proof is on the prosecution to prove that the accused is guilty. Second is that an accused is presumed to be innocent until he is

\footnotetext{
${ }^{1}$ Presented at the International Conference on "Multidisciplinary Facets for Development in Health Laws", organized by Manipal University Jaipur India School of Law in collaboration with Bio Forensics Research Center, Italy, 16-17 July 2021.

${ }^{2}$ Associate Professor, University Institute of Legal Studies, Chandigarh University, Gharuan, Mohali, Punjab.

${ }^{3} \mathrm{G}$. Swarup, Self-Incrimination Doctrine and the Right to Silence, www.workbepress.com/articles, visited on 30 June, 2021.

${ }^{4}$ One Hundred Eightieth Report on Article 20(3) of The Constitution of India and The Right to Silence, Law Commission of India, May 2002.
}

CONSTITUTIONAL LAW REVIEW 


\section{Changing dimensions of right against self-incrimination: an analytical study}

proved to be guilty. A third is that the accused cannot be compelled to give evidence against himself". The "right to silence" is based on common law and it means that no negative presumption will be taken against the merely because he has refused to respond to questions asked either by the police or by the Court. The origins of this right are somewhere in the Middle Ages in England ${ }^{6}$. However, till the late $16^{\text {th }}$ Century and early $17^{\text {th }}$ Century this principle was not developed properly. This was because of the ecclesiastic courts, the Star Chamber and the High Commission whose procedure was not protecting the rights of the accused. The judges were having power to interrogate an accused under oath 7 . The courts used to punish the accused or suspect if he refuses to testify and the practice of torture was also followed by these courts during interrogation of the accused. Further, the interrogation was carried even before the imposition of the charge against the accused. However, these courts were abolished in the year $1641^{8}$. The situation was changed after the abolition of these courts as the accused was not required to take the oath. However, the right was not properly protected because the accused was required to defend himself and no defense and right to representation through lawyer was available to the accused. It was with the incorporation of Criminal Evidence Act in 1898 in England that the accused was treated as a competent witness rather than compelling him to be a witness. It results in the recognition of his right to testify rather than a mere obligation to testify. This Act allowed the judges to disclose to the jury members choosing about the right to remain silent by the accused. This disclosure was however restricted to that extent that the presumption of guilt should not be raised by the jury simply on the basis that the accused prefer to remain silent ${ }^{9}$.

\footnotetext{
${ }^{5}$ D.D. Basu, Shorter Constitution of India, Eleven Edition, Prentice Hall of India Pvt. Ltd., New Delhi, 1994, p. 178.

${ }^{6}$ What the history of the English common law privilege does show is that the privilege was broadly conceived and applied... it was not originally limited to incrimination, but protected against loss of reputation; it was not limited to defendants, but protected witnesses; and it was not limited to judicial proceedings, but came to restrict all of the agencies which then engaged in interrogation. It was asserted in adjudicative proceedings, pre-adjudicative examinations, and even in pre-charge inquiries. It was used as a defense against the Oath ex Officio, but also to fend off unsworn examination.

${ }^{7}$ L. Levy, Origins of the Fifth Amendment: The Right against Self-Incrimination, $2^{\text {nd }}$ edition, Macmillan Publications, New York, 1986, pp. 23 \& 24.

${ }^{8}$ E. Skinnider, F. Gordon, The Right to Silence: International Norms and Domestic Realities, Sino Canadian International Conference on the Ratification and Implementation of Human Rights Covenants, Beijing, 25-26 October 2001.

${ }^{9}$ In Sorby v. Commonwealth (1983) 46 ALR 237, 244, Gibbs CJ explained the limits in scope of the testimonial disclosure rule: The privilege prohibits the compulsion of the witness to give testimony, but it does not prohibit the giving of evidence, against the will of the witness, as to the condition of his body. For example, the witness may be required to provide a fingerprint, or to show his face or some other part of his body so that he may be identified, or to speak or to write so that the jury or another witness may hear his voice or compare his handwriting. That this was the significance of the distinction between "testimonial" and other disclosures was recognized in $R v$. McLellan, where it was held that the protection afforded by the rule against self-incrimination did not extend to entitle a person who had been arrested to refuse to furnish a sample of his breath for analysis when required to do so.
}

Articles. AnALysis and Reflections 


\section{International aspect of right against self-incrimination}

There are different conventions and declarations which incorporate the privilege against self-incrimination as Right to Silence. Universal Declaration of Human Rights, $1948^{10}$, The International Covenant on Civil and Political Rights, $1966^{11}$, The European Convention for the Protection of Human Rights and Fundamental Freedoms ${ }^{12}$, The American Convention on Human Rights, $1978^{13}$ The African (Banjul) Charter on Human and Peoples' Rights, $1981^{14}$ The Cairo Declaration on Human Rights in Islam ${ }^{15}$.

\section{Indian law and right against self-incrimination}

Article 20 (3) of the Constitution of India incorporates the Right against selfincrimination ${ }^{16}$. The Article provides that no person can be compelled to be a witness against himself. The main components of this privilege are:

1. The accused is presumed to be innocent.

2. It is for the prosecution to establish his guilt.

3. The accused cannot be compelled to give any statement against his will.

\footnotetext{
${ }^{10}$ Article 11 thereof reads: "Everyone charged with a penal offence has the right to be presumed innocent until proved guilty according to law in a public trial at which he has had all the guarantees necessary for his defense".

${ }^{11}$ Article 14 (3) (g) refers to various "minimum guarantees" and states that everyone has a right, not to be compelled to testify against himself or to confess guilt". International Covenant on Civil and Political Rights (adopted 16 December 1966, entered into force 23 March 1976).

${ }^{12}$ Article 6 (1) that every person charged has a right to a 'fair' trial and Article 6 (2) thereof states: "Everyone charged with a criminal offence shall be presumed innocent until proved guilty according to law". European Convention on the Protection of Human Rights and Fundamental Freedoms (1950).

${ }^{13}$ American Convention on Human Rights (entered into force 18 July 1978). Article 8 states that every person accused of a criminal offence has the right to be presumed innocent so long as his guilt has not been proven according to law; the right not to be compelled to be a witness against himself or to plead guilty; and that a confession of guilt by the accused shall be valid only if it is made without coercion of any kind.

${ }^{14}$ African Charter on Human and Peoples' Rights (adopted 27 June 1981, entered into force 21 October 1986). Article 7 provides the right to be presumed innocent until proved guilty by a competent court or tribunal.

15 The Cairo Declaration on Human Rights in Islam, 1990. Article 19 provides that a defendant is innocent until guilt is proven in a fast trial in which he shall be given all the guarantees of defense.

${ }^{16}$ The common features discernible from the analysis of some of the statues in India in the previous paragraphs may be summarized as follows:

i. Article 20 (3) does not prohibit the Investigating Officer from putting questions to the accused to elicit information about the commission of the crime and his involvement.

ii. The court can put any questions to the accused during trial to give him an opportunity to explain the circumstances appearing against him in the evidence.

iii. The accused has a right to answer or refuse to answer any question put to him during investigation or trial.

iv. The court can draw appropriate inferences from the answers given by the accused when examined under Section 313 of the Code.

v. There is no express provision empowering the court to draw an adverse inference against the accused on his failure to answer the questions put to him.

vi. On the accused failing to rebut the statutory presumption the court can proceed to treat the presumption as absolute.
}

\section{CONSTITUTIONAL LAW REVIEW}




\section{Changing dimensions of right against self-incrimination: an analytical study}

This right of self-incrimination limits the power of the State to acquire and present evidence before the Court as the Supreme Court of India in different cases has made it clear by interpretation of Article 20 (3) that this right against selfincrimination is applicable in case of oral as well as documentary evidence ${ }^{17}$. The prosecution or state thus cannot present the evidence which are taken from the accused orally or in the form of documents. Moreover, this right enables the maintenance of privacy of the accused as well which is interpreted as a fundamental right under Article $21^{18}$ of the Indian Constitution by the Supreme Court of India in the case of Justice K. S. Puttaswamy v. Union of India ${ }^{19}$. Further, Article 21 of the Indian Constitution also emphasizes that the rights of the accused cannot be taken away except by a procedure laid down by the law which should be just, fair and equitable as laid down in case of Maneka Gandhi v. Union of India ${ }^{20}$ by the Supreme Court of India. Thus, in order to take the right under Article 20 (3) of the Indian Constitution, it is required that due procedure established by law is followed and if such procedure is not fair or justified then it can be declared as unconstitutional by Indian Supreme Court.

The Code of Criminal Procedure, 197321, also contains several protections in relation to establishing the procedure regarding the protection of the right of the accused as in Section $161^{22}$, Section $313^{23}$, Section $315^{24}$.

\section{What constitutes incrimination for the purpose of Article 20 (3)}

In the case of Smt. Selvi v. State of Karnataka ${ }^{25}$, The Hon'ble Supreme Court has laid down that there are various circumstances that could expose a person to a criminal charge. The court laid down that there can be different ways by which the incrimination can be possible in relation to the accused.

\footnotetext{
${ }^{17}$ M.P. Jain, Constitution of India, $5^{\text {th }}$ edition, Wadhwa Publishing, Nagpur, 2006, p. 1244.

${ }^{18}$ Article 21 of the Indian Constitution provides the Right to Life and Personal Liberty.

${ }^{19}$ (2017) 10 SCC 1.

2019781 SCC 248.

${ }^{21}$ Ratanlal and Dhirajlal, Code of Criminal Procedure, $17^{\text {th }}$ edition, Wadhwa and Company, Nagpur, 2007.

${ }^{22}$ Sub sec. (2) of sec. 161 of the Code of Criminal Procedure, 1973 grants a right to silence during interrogation by
} police. It reads as follows:

"Sec. 161(2): Such person shall be bound to answer truly all questions relating to such a case put to him by such officer, other than questions the answers to which would have tendency to expose him to a criminal charge or to a penalty or forfeiture".

${ }^{23}$ See Section 313 of Criminal Procedure Code, 1973. It reads as follows:

"313 (3): The accused shall not render himself liable to punishment by refusing to answer such questions, or by giving false answers to them".

${ }^{24}$ See Section 315 of Criminal Procedure Code, 1973. Subsection (1) of sec. 315 contains a proviso and clause (b) of the said proviso precludes any comment by any of the parties or the court in regard to the failure of the accused to give evidence. It reads as follows:

"Provided that - (b) his failure to give evidence shall not be made the subject of any comment by any of the parties or the court or give rise to any presumption against himself or any person charged together with him at the same trial".

${ }^{25} 2010$ (3) Law Herald (SC) 1969, at p. 2007. 
- It can be in the form of an incriminatory statement obtained on the basis of the compulsion that will be in violation of Right in case the prosecution is relying on the same.

- In another form it can be the kind of information which could lead to the discovery in relation to the offence with which the accused is charged.

- It can be in the form of transactional information which is presented by the prosecution and can be helpful in proving the case against the accused or suspect.

- It can also be in the form of information which is compared with other or along with other information like handwriting samples and specimen signatures, Blood samples, DNA etc.

\section{At what stage Article 20 (3) will operate}

The prohibition under Article 20 (3) starts at the stage of police interrogation ${ }^{26}$. In Article 20 (3), the expression "accused of any offence" includes a person against whom formal accusation has been made in relation to the offence ${ }^{27}$. It is not limited to the forensic examination and is applicable to furnishing and collection of information and materials at the time of police investigation as well ${ }^{28}$.

The Supreme Court in the case of Raja Narayan Lal v. Manek Phiroz Mistry ${ }^{29}$ observed that Testimonial Compulsion is protected under Article 20 (3) of the Indian Constitution. In this case what is to be considered more important is that formal accusation has been made against the accused. Thus, as per the court in this case, the Formal accusation is a stage on which Article 20 (3) will operate as a right to protect the accused against self-incrimination.

In the Case of Kathi Kalu Oghad, J. Sinha, while speaking for the majority ${ }^{30}$ stated that in order to make Article 20 (3) of the Indian Constitution as applicable, the person must be accused of an offence when he has made the statement. Although it does not matter for the applicability of the Article 20 (3) that the statement should be related with the same time when he is charged with the offence, it can be made at any time after his formal accusation. Further, the right is applicable even when there is just a tendency that the statement will result in the incrimination of the accused.

Generally, it is after the filing of an FIR or complaint against the person that he is considered as an accused of the offence ${ }^{31}$. Thus, after this stage, every statement which is taken from the accused involuntarily can be included in the privilege of Self-incrimination ${ }^{32}$.

\footnotetext{
${ }^{26}$ Nandini Satpathy v. P.L. Dani AIR 1978 SC 1025.

${ }^{27}$ Miranda v. Arizona (1966) 384 US 436.

${ }^{28}$ U.S. Srivastava, Immunity from Self Incrimination under Article 20 (3) of The Constitution of India, available at ijtr.nic.in/articles/art19.pdf (Visited on $22^{\text {nd }}$ June, 2021.)

${ }^{29}$ AIR 1961 SC 29.

${ }^{30}$ Kathi kalu Oghad v. State AIR 1961 SC 1808.

${ }^{31}$ R.C. Mehta v. State (1969) 2 SCR 461.

${ }^{32}$ M.P. Sharma v. State AIR 1954 SC 300.
}

CONSTITUTIONAL LAW REVIEW 


\section{Changing dimensions of right against self-incrimination: an analytical study}

\section{When can testimony be castigated as compelled}

The rule applies to questions not only related to direct criminal acts, but as to perfectly innocent material which forms a chain of proof against the accused ${ }^{33}$. In order that testimony by an accused person can be said to be self-incriminatory, the compulsion can include blood on clothes, gold bars with notorious marks and presence on the scene or possession of lethal weapons ${ }^{34}$.

\section{Testimonial compulsion, scientific advancement and right against self-incrimination}

There are some questions which are required to be considered so that it can be analyzed whether the technology and scientific evidence has diluted the right against self-incrimination available to the accused. In this context there is a need to study two issues in detail:

1. Whether taking a sample of the accused without his or her consent is in violation of Article 20 (3) of the Constitution or not?

2. Whether subjecting the accused to examination by modern techniques is valid or not?

Whether taking a sample of the accused without his or her consent is in violation of Article 20 (3) of the Constitution or not?

Self-incrimination means conveying information based on the personal information of the person giving the information and cannot include merely the mechanical process of producing the documents in the court which may throw light on any of the points in controversy. When an accused is called upon by the investigating agencies or the court to give his finger impression, handwriting etc., it cannot be treated as personal testimony of the accused ${ }^{35}$. In order to determine this issue, the help can be taken from the various decisions and case laws of different courts. In Ram Lal's case the SC observed that taking of blood sample cannot be termed as testimonial or compelling the accused to be a witness against himself ${ }^{36}$. In the case of Goutam Kundu v. State of West Benga ${ }^{37}$, where the issue in question was relating to the paternity of the child, the Court has laid down certain guidelines that the Blood test cannot be ordered until and unless there is a strong and prima facie

\footnotetext{
${ }^{33}$ Nandini Satpathy v. P. L. Dani AIR 1978 SC 1025 at p. 1044.

${ }^{34}$ Kathi Kalu Oghad v. State AIR 1961 SC 1808.

${ }^{35}$ M.P. Sharma v. Satish Chandra (1954) SCR 1077. See also Deoman Shamji Patel v. State of Maharashtra AIR 1959 Bom 284.

${ }^{36}$ AIR 1979 SC 1791.

${ }^{37}$ AIR 1993 SC 2295.
}

ARTICLES. AnALYSIS AND REFLECTIONS 
case against the accused. Further, the court held that before ordering the consent, the court must clearly examine that it is absolutely required in the case and in no case the accused will be compelled to give evidence.

In the case of Hargovind Soni v. Ramdulari ${ }^{38}$, it was held by the High Court that the blood grouping test is a perfect test to determine the question of disputed paternity of a child and can be relied upon by courts as circumstantial evidence. But no person can be compelled to give a sample of blood against his wish and no adverse inference can be drawn against him for his refusal.

P.A. Anbu Anandan v. State ${ }^{39}$, the question before the court was as to whether there has been consummation of marriage. Following the Gautam Kundu case, the court held that the court cannot compel a person for compulsory medical examination of the party against his wish.

However, in Sharda v. Dharmpal ${ }^{40}$, the SC overrules its prior decision in Gautam Kundu case and lays down that the case is not an authority for the supposition that under no circumstances the court can direct that blood tests be conducted. What is required to be considered is that the court should not choose any mechanical process for deciding the same. The Court held that if a matrimonial court passes the order for such a test then it will be within the power of the court and cannot be considered as in violation of the right of the accused. If despite the order of the Court, the person refuses to undergo the test, adverse inference can be drawn against him.

H.M.Prakash@Dali v. State of Karnataka ${ }^{41}$, when the court has clearly held that the criminal court can make a direction for a blood test of the accused under Section 53 of the Code depending on the facts and circumstances of the case to find out the guilt or innocence of the accused and the said direction is not in violation of the constitutional right of the accused. Again, the Madras High Court has observed that compulsory taking of test or samples of blood from the accused is not hit by Article 20 (3) of the Constitution as it is not testimonial compulsion ${ }^{42}$.

In Hallappa v. State of Karnataka ${ }^{43}$, the Karnataka High Court dealing with Section 53 A observed that drawing of blood sample for the detection of the offence of rape where the investigation agency has to establish its case beyond reasonable doubt, it cannot be termed as in violation of Article 20 (3) of the Constitution. The offence of rape is a very serious offence and it is the offence against the society at large. Further, obtaining the blood sample will not incriminate him. The characteristics of blood cannot be altered. Only on the comparison with semen and blood stains found on the apparels of the accused or the victim, if the result is positive, only then it will

\footnotetext{
${ }^{38}$ AIR 1986 Madhya Pradesh 57.

${ }^{39}$ AIR 1999 Madras 232.

${ }^{40}$ AIR 2003 SC 3450.

${ }^{41}$ AIR 2004 Kant HCR 1485.

${ }^{42}$ AIR 1959 Mad 396.

${ }^{43} 2010$ Cri LJ 4341.
} 


\section{Changing dimensions of right against self-incrimination: an analytical study}

incriminate the accused. This being the position, it is difficult to say that drawing of blood sample for the purpose of detection of crime of rape is in violation of Article 20 (3) of the Constitution.

Thus, from the above discussion it is clear that taking of the sample of blood of the accused is not in violation of the prohibition against self-incrimination. Insertion of this particular provision has also been recommended by the Law Commission of India ${ }^{44}$.

\section{Whether subjecting the accused to examination by modern techniques is valid or not?}

In considering this aspect, the researcher has analyzed the use of different scientific advancement like DNA, Narco Analysis, Brain Mapping, Polygraph test etc. to see whether the impact and use of these techniques is resulting in violation of Right against self-incrimination.

DNA and Right against Self Incrimination: The term DNA means "Deoxyribonucleic acid". It is present in the most living cells in human body and its structure is unique to every single individual, the only exception being twins. The most common source of DNA is usually a sample from blood, semen, hair roots ${ }^{45}$. These are popular because they are available without popular intrusion. The complete analysis of DNA is known as "DNA Profiling". It is essentially a biological tool which allows the scientist to compare samples of DNA. It is perhaps the most reliable and conclusive method of personal identification ${ }^{46}$. The Supreme Court of India has accepted the accuracy of this test and observed that the result of the DNA test is scientifically true ${ }^{47}$.

It must also be clarified that a DNA Profile is different from a DNA Sample which can be obtained from the bodily substances. DNA Profiling is a record created on the basis of DNA samples that is made available to the forensic experts. Creating and maintaining DNA profiles of the criminals and suspects are useful practices since newly obtained DNA Samples can be readily matched with existing profiles that are already in the possession of law enforcement agencies ${ }^{48}$. Even if it is accepted for the sake of argument that a DNA test becomes favorable to the accused concerned, that would not absolve him from the charges brought against him if there is sufficient evidence pointing to the guilt of the accused ${ }^{49}$.

\footnotetext{
${ }^{44}$ For further details, see $37^{\text {th }}$ Law Commission Report on Criminal Procedure Code, 1898, Dec. 1967 and $41^{\text {st }}$ Law Commission Report on Code of Criminal Procedure, Sept. 1969.

${ }^{45}$ N. Joshi, Medical Jurisprudence and Toxicology, Kamal Publications, New Delhi, 2008, pp. 92-111 at p. 92.

${ }^{46}$ Sankaran Narayan and Viney Reddy, "DNA Testing: Opening New Horizons for Criminal Justice in India, Health Care, Policy, Ethics and Law, Vol. 8, April 2001, pp. 94-104.

${ }^{47}$ See Smt. Kanti Devi v. Poshi Ram AIR 2001 SC 2226. See also Anant Kumar v. State of Andhra Pradesh 1977 Cri LJ 1797, Jamshed v. State of U.P. 1976 Cri L 1680.

${ }^{48}$ Supra note 21 at 2032.

${ }^{49}$ Sabur Hossain Biswas v. State of West Bengal and Others 2008 Cri LJ 1183.
} 
In recent times, the parenthood of the child is decided by the courts based on DNA testing. Various courts have approved and acknowledged its potential as an effective aid in identification and investigating processe ${ }^{50}$. Comprehensive use of forensic science has been suggested by the Malimath Committee from its very inception $^{51}$. It has been observed by the Bombay and Rajasthan High Court that the taking of blood samples for the purpose of DNA is in no way in violation of the provisions of the Constitution under Article $20(3)^{52}$. Rather it is recommended that DNA experts should be included in Subsection 4 of Section 293 of the Code ${ }^{53}$. From the above discussion, it is clear that a DNA test is valid and it does not violate the right of the person concerned ${ }^{54}$. Rather it is helpful in identification of persons in cases of rape, exchange of babies, immigration, infanticide, bombings etc. ${ }^{55}$.

Narco Analysis, Polygraph Test, Brain Mapping and Right against Self Incrimination: Narco analysis is one such scientific development that police authorities in India desire to use for the purpose of investigation. It is a psychoanalytical test which is used to interpret the behavior of the criminal. In the case of Narco Analysis Test, the imagination of the person undergoing the test is neutralized by making him semiconscious. In this State, it becomes difficult for him to lie and his answers would be restricted to facts he is already aware of. Experts inject the subject with Sodium Pentothal or Sodium Amytal. The dose of the same depends on the sex, age, health and physical condition of the person. The subject is not in a position to speak up on his own but can answer specific yet simple questions. The answers are believed to be spontaneous as a semi-conscious person is unable to manipulate the answers.

Polygraph or lie detection test is an examination, which is based on an assumption that there is an interaction between the mind and body and is conducted by various components or the sensors of a polygraph machine, which are attached to the body of the person at the time when the investigation is made by an expert ${ }^{56}$. The machine records the blood pressure, pulse rate and respiration and muscle movements. Polygraph test is conducted in three phases which includes a pre-test interview, chart recording and diagnosis ${ }^{57}$.

In the P300 or brain mapping test, the subject is first interviewed and

\footnotetext{
${ }^{50}$ S.S. Nagar Priyatham, A. Sumanth, DNA Testing, Evidence Act and Expert Witness, AUU, Vol. 4, 2003, p. 225.

${ }^{51}$ See Malimath Committee Report on Criminal Justice System, 2003.

${ }^{52}$ See Anil Anantrao Lokhande v. State of Maharashtra 1981 Cri LJ 125 (Bom.). See also Miss Swati Lodha v. State of Rajasthan 1991 Cri L 939 (Raj).

${ }^{53}$ Committee on Reforms of Criminal Justice System, Government of India, Ministry of Home Affairs, 2002.

${ }^{54}$ Report of The Committee on Draft National Policy on Criminal Justice, Ministry of Home Affairs, Government of India, July 2007.

${ }^{55}$ Kamrin T. Macknight, The Polymerse Chain Reaction: The Second Generation of DNA Analysis Methods Takes the Stand, Computer and High Technology Journal, Vol. 20, 2003, p. 103.

${ }^{56}$ National Research Council 2003. The Polygraph and Lie Detection. Washington, DC: The National Academies Press, https://doi.org/10.17226/10420.

${ }^{57}$ E.H. Meijer, B. Verschuere, The Polygraph and Detection of Deception, Journal of Forensic Psychology Practice, Vol. 10, pp. 325-338 at 326 (July 2010).
} 


\section{Changing dimensions of right against self-incrimination: an analytical study}

interrogated to find out whether he is concealing the truth or any information. The activation of the brain for associated memory is carried out by presenting a list of words to the subject ${ }^{58}$. There are three types of words used in the list for Brain Mapping. Part I consists of those words which have no direct relationship with the case. Part II consists of probe words directly related to the case and Part III consists of target, which are not the part of the first two parts. The words in this part consist of confidential parts which the suspect does not know ${ }^{59}$.

Although these tests represent scientific advancement, yet questions are often raised about the validity of tests on the basis of invalidity in relation to applicability of legal principles and constitutional provisions ${ }^{60}$.

In a significant judgment of Dinesh Dalmia v. State ${ }^{61}$, the Madras High Court held that subjecting an accused to Narco analysis is not necessarily to be considered as a testimony by compulsion. The court held that even at the time of undertaking the process of tests, the compulsion can be there but after the administration of the drug, when the person gives the statement, which is voluntary as at that time no one compels the person to give a statement.

However, the most important question that is required to be considered here is whether actually it is a voluntary in reality as the person is in sub conscious stage whereby he is unable to give his consent which cannot be treated as valid consent as per the laws of India.

In Santokben Sharmanbhai Jadeja v. State of Gujarat ${ }^{62}$, the Court has justified the carrying out of these tests on the ground that when there is no other way to take or collect the evidence against the accused, then this can be considered as the best way to get the information from the accused.

However, all the previous controversial and contradictory decisions were settled by the Supreme Court of India in the landmark judgment of Smt. Selvi v. State of Karnataka ${ }^{63}$ in which the Court has made it clear that involuntary administration of Narco analysis, brain mapping or lie detector test is an infringement of Right against self-incrimination. The Supreme Court has specifically made it clear that these kinds of scientific tests are in violation of the right to privacy, especially mental privacy ${ }^{64}$. This judgment of the Supreme Court is followed as a precedent in other cases as well and

\footnotetext{
${ }^{58}$ Available at http://www.legalserviceindia.com/medicolegal/Brain-Mapping-Test.htm (Visited on $24^{\text {th }}$ June, 2021).

${ }^{59} \mathrm{H}$. Wang, W. Chang, C. Zhang, Functional brain network and multichannel analysis for the P300-based Brain Computer Interface system of lying detection, Expert Systems with Applications, Vol. 53, 117-128 at 119 (2016).

${ }^{60}$ Is Narco Analysis a Reliable Science? Present Legal Scenario In India, available at www.legalservices.com (Visited on $24^{\text {th }}$ June, 2021).

${ }^{61} 2006$ CriLJ 2401 (Mad).

622008 CriLJ 68 (Guj).

${ }^{63}$ Supra note, 21.

${ }^{64} \mathrm{~K}$. Rajagopal, Involuntary Narco tests an intrusion into a person's mental privacy: Supreme Court, The Hindu, $4^{\text {th }}$ October, 2020, available at https://www.the hindu.com/news/national/involuntary-narco-tests-anintrusion-into-a-persons-mental-privacy-sc/ article32766457.ece (Visited on $1^{\text {st }}$ July, 2021).
}

ARTICLES. AnALYSIS AND REFLECTIONS 
further makes it clear that even though the tests like Narco analysis, brain mapping etc. may be necessary to get evidence against the accused, however, it cannot overpower the protection against self-incrimination. Further, the Supreme Court has gone to this extent that the Accused cannot use these scientific tests for proving his innocence ${ }^{65}$.

\section{Conclusions}

Thus, after analyzing all the aspects of the Right against Self Incrimination and applicability of the right in relation to the adoption of the new techniques for carrying out investigation that it can be safely concluded that even after the advent of the new technology for taking scientific evidence, it has not resulted in the dilution of the right against self-incrimination as provided under the Indian Constitution.

1. Right against self-incrimination is a Fundamental Right provided under Article 20 (3) of Indian Constitution where the person cannot be compelled to be a witness against himself.

2. Right against self-incrimination is applicable to involuntary statements.

3. Right against self-incrimination extends to both oral and documentary evidence.

4. Right against self-incrimination is applicable in case of formal accusation of the accused.

5. Right against self-incrimination is applicable in case of direct and indirect criminal acts including the completely innocent statement when combined with the other statement or evidence.

6. Right against self-incrimination is not applicable to the samples such as fingerprints, thumb impressions, writing specimen.

7. Taking a blood sample of the accused without his consent is not in violation of Right against Self-incrimination.

8. Taking a DNA sample of accused with or without consent is not in violation of Right against self-incrimination.

9. Narco Analysis Test, Lie Detector Test and Brain Mapping Test is in direct violation of the Right against self-incrimination. If these tests are conducted without the consent of the accused, then it is unconstitutional.

10. The Supreme Court of India is able to protect the Right of the accused in relation to privilege against self-incrimination even after the advent of different scientific technologies threatening the existence of the right.

${ }^{65}$ Sidhu Yadav v. State of NCT of Delhi, High Court of Delhi, Criminal Miscellaneous (Main) No. 1150 of 2017. See also Supreme Court enunciates: No Accused can say the Police must conduct the Narco Analysis Test on him, available at https://www.latestlaws.com/latest-news/supreme-court-enunciates-no-accused-can-say-policemust-conduct-narco-analysis-test (Visited on $24^{\text {th }}$ June, 2021). 